\title{
Phacoemulsification and foldable acrylic IOL implantation in children with treated retinoblastoma
}

\author{
Facoemulsificação e implante de lente intraocular acrílica dobrável em crianças com retinoblastoma \\ Marcia Beatriz Tartarella ${ }^{1}$, Gloria Fátima Britez-Colombi ${ }^{1}$, Marcia Motono², Martha Motono Chojniak², Joao Borges Fortes Filho ${ }^{3}$, Rubens Belfort Jr. ${ }^{1}$
}

\begin{abstract}
Purpose: To study the results of cataract surgery in children with radiation-induced cataract after treatment for retinoblastoma.

Methods: Retrospective interventional case series. Six consecutive patients diagnosed with secondary cataracts due to radiation therapy for retinoblastoma. Intervention: Phacoemulsification and foldable acrylic intraocular lens implantation. Outcomes measured: Visual acuity, binocular indirect ophthalmoscopy and slit-lamp biomicroscopy. Aspirated lens material and aqueous humor samples were collected during surgery. Results: Six uniocular children between 3 to 5 years of age at time of surgery were studied. The mean time interval between radiotherapy and cataract diagnosis was 22.3 months. The mean follow-up after surgery was 17.2 months (range: 12 to 23 months). All eyes achieved a clear visual axis after surgery allowing monitoring of the tumor status. None developed recurrence or retinoblastoma dissemination. Histopathological analysis of the aspired material showed no tumoral cells in all samples. All patients improved vision after cataract surgery.

Conclusions: Phacoemulsification with acrylic intraocular lens implantation seems to be a safe, feasible, and effective method for the removal of radiation-induced cataracts in patients with treated retinoblastoma.
\end{abstract}

Keywords: Retinoblastoma/cirurgia; Retinoblastoma/radiotherapy; Retinal neoplasms/radiotherapy; Cataract/etiology; Eye enucleation; Radiation injuries; Radiotherapy/adverse; Lens implantation, intraocular; Humans; Child

\section{RESUMO}

Objetivos: Estudar os resultados da cirurgia da catarata induzida pela radioterapia para o tratamento do retinoblastoma em crianças.

Métodos: Estudo retrospectivo intervencional em série de casos onde seis pacientes consecutivos apresentaram catarata secundária à terapia por radiação para o retinoblastoma. Intervenção: Facoemulsificação e implante de lente intraocular acrílica dobrável. Foram avaliadas: acuidade visual, oftalmoscopia binocular indireta e biomicroscopia. Material para análise histológica do cristalino e do humor aquoso foi coletado durante as cirurgias. Resultados: Seis crianças, entre 3 e 5 anos de idade, com catarata secundária à radiação para tratamento de retinoblastoma foram submetidas à cirurgia de facoemulsificação com implante de lente intraocular. A média do intervalo de tempo decorrido entre a radioterapia e o diagnóstico da catarata foi 22,3 meses. O período médio de seguimento após a cirurgia foi de 17,2 meses (intervalo: 12 a 23 meses). Todos os olhos melhoraram a visão e mantiveram eixo visual livre permitindo a fundoscopia para monitorar o tumor. Nenhum paciente evoluiu com recorrência ou disseminação do retinoblastoma. A análise histopatológica do material colhido resultouem ausênciade células tumorais nas amostras. Conclusões: A cirurgia de facoemulsificação com implante de lente intraocular acrílica dobrável mostrou ser um procedimento seguro e efetivo para o tratamento da catarata induzida pela radioterapia em pacientes portadores de retinoblastoma.

Descritores: Retinoblastoma/cirurgia; Retinoblastoma/radioterapia; Neoplasisas da retina/radioterapia; Catarata/etiologia; Enucleação ocular; Lesões por radiação; Radioterapia/efeitos adversos; Implante de lente intraocular; Humanos; Criança

\section{INTRODUCTION}

Retinoblastoma (RB) is the most common intraocular malignancy in childhood, occurring in approximately 1 of 20,000 live births ${ }^{(1)}$.

The goals of management of RB are, first, to preserve life and, second, to salvage the eye and restore vision if possible ${ }^{(2)}$. Earlier diagnosis coupled with new therapeutic modalities such as External Beam Radiotherapy (EBRT), radioactive plaque and brachytherapy have allowed successful treatment avoiding enucleation in many cases $^{(1-5)}$.

About $20 \%$ to $87 \%$ of the patients treated with radiotherapy can develop a radiation-induced secondary cataract blocking the visual axis and therefore causing severe reduction of visual acuity $(V A)^{(6-8)}$.

Maintenance of a clear visual axis is important in order to allow the examination of the eye fundus and to observe the regressed retinoblastoma lesions ${ }^{(9)}$.

The purpose of this study was to evaluate the visual outcome and ocular complications of the cataract surgery by phacoemulsification and foldable acrylic intraocular lens implantation (IOL) in children with radiation-induced cataract after treatment for RB.

\section{METHODS}

Six uniocular patients with secondary cataract due to radiation therapy for RB treatment were submitted to phacoemulsification and IOL implantation at the Congenital Cataract Section, Department of Ophthalmology, Federal University of Sao Paulo SP, Brazil. During surgery, a sample of aqueous humor $(0.2 \mathrm{ml})$ was collected from the anterior chamber for analysis. Aspirated lens material $(0.2 \mathrm{ml})$ was also sent for histopathological analysis.

Table 1 presents the age (in months) of patients at RB diagnosis, the different prescribed treatments, and the time interval between radiotherapy and the diagnosis of cataract. All patients had bilateral $\mathrm{RB}$, and all of them had one eye previously enucleated. All eyes had 
inactive tumors when they presented for cataract surgery. Lens opacities hindered fundus examination in all patients.

Visual acuity was measured with Snellen acuity cards, Teller Acuity Cards or Lea Hyvarigen Acuity Cards depending on patient collaboration. Final best corrected visual acuity (BCVA) was obtained at the last followup visit.

Calculation of the IOL power was based on previous studies of axial length growth in pseudophakic eyes of children with lamellar cataract, as follows: children aged 3 to 4 years had a 10\% reduction of the calculated IOL power. Children between 4 and 6 years had an addition of $0.75 \%$ on the preoperative axial length in order to calculate the final IOL diopter(10).

The same surgeon (MBT) operated on all cases using the same technique. A clear corneal tunnel incision was performed and a lateral paracentesis was used to allow the introduction of any additional instrument during phacoemulsification. Viscoelastic substance (Viscoat ${ }^{\circledR}$ ) was used to fill the anterior chamber. An anterior continuous circular capsulorhexis followed by hydrodissection and hydrodeliniation were performed. Phacoemulsification or phacoaspiration of the lens was performed followed by a meticulous aspiration of lens material. A foldable acrylic IOL (AcrySof ${ }^{\circledR}$ ) was implanted within the capsular bag. Next step included aspiration of the viscoelastic substance from the anterior chamber and injection of a miotic drug $\left(\right.$ Miostat $\left.{ }^{\circledR}\right)$. One or two single sutures (mononylon 10-0) were used to achieve a safe closure of the corneal incision. Subconjuntival dexamethasone $(0.5 \mathrm{mg} / 1 \mathrm{ml})$ and gentamicin $(40 \mathrm{mg} / 1 \mathrm{ml}$ ) were injected at the end of surgery. Topical antibiotics and corticosteroids were applied for the first two weeks after surgery and tapered during 2 months of follow-up.

Visual acuity, binocular indirect ophthalmoscopy and slit lamp examination were assessed on all postoperative visits.

\section{RESULTS}

Patients were between 3 and 5 years-old (mean 4.9 years-old) at the time of cataract surgery. Three eyes presented nuclear cataract and three eyes presented posterior sub-capsular cataract. Mean time between radiotherapy and cataract diagnosis was 22.3 months. All patients included in this study showed initial VA worse than 20/200. All children improved VA after surgery (Table 2). Mean postoperative follow-up was 17.2 months (12 to 23 months).

A posterior paracentral capsule opacification (PCO) was observed during surgery in three eyes (patients \#2, \#4 and \#5) but the capsule was left intact. No patient needed a Neodimium YAG laser posterior capsulotomy.

Patient \#4 presented an inflammatory membrane anterior to the IOL that disappeared within two weeks after surgery.

One eye (patient \#3) developed a paracentral mild PCO during the follow-up. This PCO did not affect VA or eye fundus examination (Figure 2).

Table 1. Retinoblastoma diagnosis, therapy and time interval between radiotherapy and cataract development

\begin{tabular}{lcccccccc}
\hline Patient & Age $^{*}$ & TTT & Cryo & Photo & Brachy & Chemo & RXT & Cataract $^{\dagger}$ \\
\hline 1 & 10 & + & + & + & 0 & + & + & 14 \\
2 & 4 & 0 & 0 & + & 0 & 0 & + & 40 \\
3 & 2 & + & + & + & 0 & + & + & 25 \\
4 & 2 & + & + & + & + & 0 & + & 14 \\
5 & 22 & + & 0 & + & 0 & + & + & 14 \\
6 & 20 & + & 0 & 0 & + & 0 & + & 24 \\
\hline
\end{tabular}

* = age in months at retinoblastoma diagnosis; $\mathrm{TTT}=$ transpupillary thermotherapy; $\mathrm{Cryo}=$ cryotherapy; Photo= phototherapy; Brachy = brachytherapy; Chemo= chemotherapy; $\mathrm{RXT}=$ radiotherapy $;+=$ therapy yes; $0=$ therapy $n{ }^{+}{ }^{+}=$time interval between radiotherapy and radiation-induced cataract (in months).
Five eyes received a three-piece acrylic hydrophobic foldable IOL (MA60AC, Alcon AcrySof ${ }^{\circledR}$ ) and one eye received a single-piece IOL (SA30AL Alcon AcrySof ${ }^{\circledR}$ ).

Intraocular lens power ranged from +21 to +29 (mean +25.5 D). Refraction was obtained and glasses with protective polycarbonate multifocal lenses were prescribed for all patients.

Slit lamp examination postoperatively showed severe dry eye with fluorescein staining in two eyes

All eyes achieved a clear visual axis after cataract surgery, allowing monitoring tumoral status (Figure 1, patient \#6). None had recurrence or spread of the tumor during the follow-up time of this study. Histopathological analysis of aqueous humor and aspirated lens material showed no tumoral cells in the samples of all patients.

\section{DISCUSSION}

Retinoblastoma is the most frequent intraocular tumor in childhood ${ }^{(1)}$ and early detection and treatment is essential. Erwenne and Franco (11) found that advanced age and delayed diagnosis increase the chance for extraocular disease that mandates significantly more aggressive treatment.

Time range between the appearance of first $\mathrm{RB}$ signs and the initial treatment as well as the management of RB influence the outcomes $^{(4)}$.

In the past, standard treatments for RB consisted of enucleation and EBRT. Systemic chemotherapy was generally reserved for patients with invasion of the optic nerve, choroid, orbit or with metastatic disease ${ }^{(1)}$. Nowadays, chemoreduction has been widely used to avoid EBRT ${ }^{(1,5)}$. Other management options in children include ra-

\section{Table 2. Visual acuity before and after cataract surgery}

\begin{tabular}{lcccc}
\hline Patient & $\begin{array}{c}\text { Age at surgery } \\
\text { (years) }\end{array}$ & $\begin{array}{c}\text { VA before } \\
\text { cataract surgery }\end{array}$ & $\begin{array}{c}\text { Follow-up } \\
\text { (months) }\end{array}$ & $\begin{array}{c}\text { Final } \\
\text { BCVA }\end{array}$ \\
\hline 1 & 3 & $20 / 570$ & 23 & $20 / 400$ \\
2 & 5 & $20 / 200$ & 12 & $20 / 30$ \\
3 & 4 & CF 2 m & 19 & $20 / 70$ \\
4 & 4 & CF 50 cm & 13 & $20 / 200$ \\
5 & 5 & LP & 16 & $20 / 60$ \\
6 & 5 & LP & 20 & $20 / 40$ \\
\hline
\end{tabular}

$\mathrm{VA}=$ visual acuity; Final $\mathrm{BCVA}=$ best corrected $\mathrm{VA}$ at last follow-up; $\mathrm{CF}=$ counting fingers vision; $\mathrm{LP}=$ light perception vision

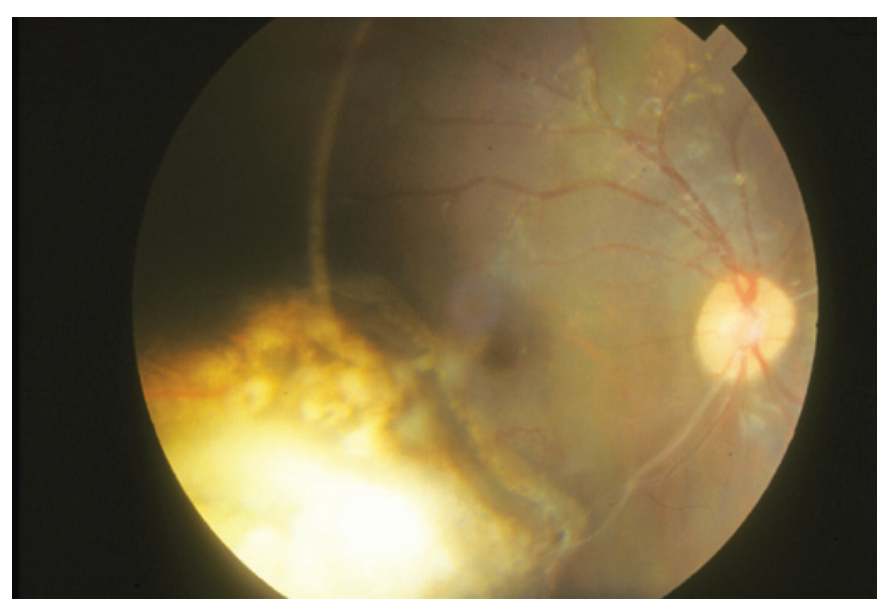

Figure 1. Patient \# 6 - Eye fundus with inactive retinoblastoma: tumor status 20 months after cataract surgery and IOL implantation. 


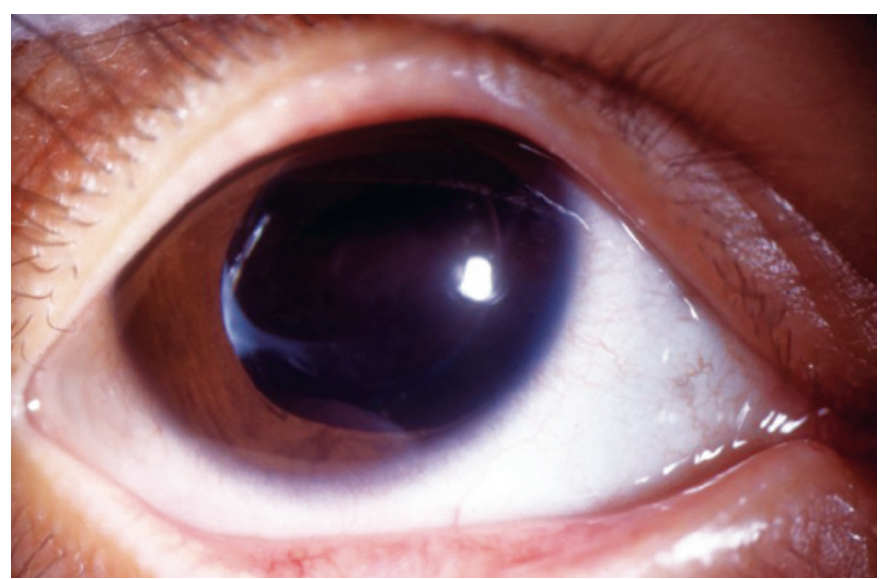

Figure 2. Patient \#3 - posterior capsule opacification.

diation therapy, photocoagulation, cryotherapy, and chemotherapy. Focal treatment modalities, as radioactive plaques, have promising prospects $s^{(4,9)}$.

Radiotherapy has been a useful modality in the treatment of RB, but lens irradiation may cause cataract induction, usually occurring 2 to 12 years after treatment ${ }^{(12)}$. In our study we found a mean latency period of 22.3 months from radiotherapy to cataract diagnosis.

Treatment of radiation-induced cataracts is similar to treatment for pediatric cataracts. The implantation of an IOL by itself may not increase the risk of recurrence of RB or systemic metastasis and could be considered for providing optimal visual rehabilitation after cataract surgery. All patients in this series improved VA, although other factors as tumor size and location, age of the patient and amblyopia may influence the final visual results.

Samples of aqueous humor and aspirated lens material were easily obtained during cataract surgery. Hadjistilianou et al., analyzed aqueous humor proteins in patients with RB and reported an increase in protein content in eyes with $\mathrm{RB}^{(13)}$. In order to investigate malignant cells, the samples were collected and a histopathological analysis was performed. The results of our study showed the absence of malignant cells in the samples.

The role of posterior capsulotomy in spreading tumor cells is yet unknown but Brooks et al. ${ }^{(3)}$, recommended avoiding posterior capsulotomy to prevent an eventual seeding of the tumor. Although posterior capsulorrhexis in children is advisable, we preferred to maintain the posterior capsule in order to respect the anatomical barrier between anterior and posterior eye segments. All children were older than 3 years-age at the time of surgery and might be able to collaborate to perform Neodimiun-YAG laser posterior capsulotomy if necessary.

Miller et al. ${ }^{(14)}$, described good results after pars plana lensectomy and IOL implantation in radiation-induced cataracts in children with RB.

Same authors ${ }^{(15)}$ reported a series of eleven eyes that underwent a primary IOL implantation after RB treatment. They concluded that IOL implantation seemed to be a safe method for aphakia correction. The authors advised penetrating the anterior chamber through a clear corneal incision to avoid direct contact with conjunctival blood vessels, scleral tissues, and vitreous management in order to reduce the risk of spreading tumoral cells ${ }^{(15)}$.

Besides tumoral spread or recurrences, the complications expected in the removal of radiation-induced cataracts are similar to pediatric cataract surgery ${ }^{(3,9,16-17)}$. In this case series no complications related to the RB occurred. All eyes studied did not develop tumor recurrence or dissemination during the follow-up period. Attention to dry eye signs and symptoms is a must in those irradiated eyes. Artificial tear drops and ointments were prescribed to two patients diagnosed with dry eye.
In three eyes a partial PCO was detected at the end of surgery, but posterior capsulotomy was not performed due to the risk of tumor dissemination. Despite the capsular opacification, indirect ophthalmoscopy was feasible and VA improved after surgery. Maintenance of a clear visual axis was obtained, allowing adequate view of the posterior pole in order to monitor the regressed tumoral lesions.

Intraocular lenses choice was important, IOL material and model are related to biocompatibility in adults ${ }^{(18,19)}$ and children ${ }^{(20-22)}$. This study showed good results with acrylic hydrophobic IOLs.

Refractive results were within the expected calculated diopters. Future changes in refraction may occur in these growing eyes. IOL power calculation was based on previous data on axial lengths in children with cataracts ${ }^{(10)}$. There are no studies of ocular growth in eyes with RB and cataracts. Predictive IOL power calculation and axial growth in eyes with RB need further investigation.

Hoehn et al. ${ }^{(23)}$, showed the effectiveness of cataract surgery to improve quality of life in affected children. The children in our study were all uniocular patients and achieved an improvement of vision that could lead to better ambulation and better integration in the community and school.

\section{CONCLUSION}

No tumor spread or recurrences were observed in this series and improvement of VA was obtained in all patients. We conclude that although the long term risk-benefit is still unknown, phacoemulsification and foldable acrylic IOL implantation in eyes with previously treated RB seems to be a feasible, safe and effective treatment for radiation-induced cataracts, but the number of included patients is too low in order to establish an outcome complication profile.

\section{REFERENCES}

1. Brichard B, De Bruycker JJ, De Potter P, Neven B, Vermylen C, Cornu G. Combined chemotherapy and local treatment in the management of intraocular retinoblastoma. Med Pediatr Oncol. 2002;38(6):411-5.

2. Honavar SG, Singh AD, Shields CL, Meadows AT, Demirce H, Cater J, et al. Postenucleation adjuvant therapy in high-risk retinoblastoma. Arch Ophthalmol. 2002; 120(7):923-31

3. Brooks HL Jr, Meyer D, Shields JA, Balas AG, Nelson LB, Fontanesi J. Removal of radiation-induced cataracts in patients treated for retinoblastoma. Arch Ophthalmol. 1990;108(12):1701-8

4. Balmer A, Munier F, Zografos L. Nouvelles stratégies dans le traitement du rétinoblastome. J Fr Ophtalmol. 2002;25:187-93.

5. Shields CL, Honavar SG, Meadows AT, Shields JA, Demirci H, Singh A, et al. Chemoreduction plus focal therapy for retinoblastoma: factors predictive of need for treatment with external beam radiotherapy or enucleation. Am J Ophthalmol. 2002;133(5):657-64. Comment in: Am J Ophthalmol. 2002;134(4):633; author reply 633-4.

6. Anteby I, Ramu N, Gradstein L, Miskin H, Pe'er J, Benezra D. Ocular and orbital complications following the treatment of retinoblastoma. Eur J Ophthalmol. 1998;8(2): 106-11.

7. Blach LE, McCormick B, Abramson DH. External beam radiation therapy and retinoblastoma: long-term results in the comparison of two techniques. Int J Radiat Oncol Biol Phys. 1996;35(1):45-51.

8. Fontanesi J, Pratt CB, Kun LE, Hustu HO, Coffey D, Meyer D. Treatment outcome and dose-response relationship in patients younger than 1 year treated for retinoblastoma with primary irradiation. Med Pediatr Oncol. 1996;26(5):297-304.

9. Honavar SG, Shields CL, Shields JA, Demirci H, d Naduvilath TJ. Intraocular surgery after treatment of retinoblastoma. Arch Ophthalmol. 2001;119:1613-21.

10. Tartarella MB. Estudo do comprimento axial em olhos de crianças portadoras de catarata lamelar bilateral [Tese]. São Paulo: Universidade Federal de São Paulo; 1998.

11. Erwenne CM, Franco EL. Age and lateness of referral as determinants of extraocular retinoblastoma. Ophthalmic Pediatr Genet. 1989;10(3):179-84.

12. Egbert PR, Donaldson SS, Moazed K, Rosenthal AR. Visual results and ocular complications following radiotherapy for retinoblastoma. Arch Ophthalmol. 1978; 96(10):1826-30.

13. Hadjistilianou T, Giglioni S, Micheli L, Vannoni D, Brogi E, Cevenini G, et al. Analysis of aqueous humour proteins in patients with retinoblastoma. Clin Experiment Ophthalmol. 2012;40(1):e8-e15.

14. Miller DM, Murray TG, Cicciarelli NL, Capo H, Markoe AM. Pars plana lensectomy and intraocular lens implantation in pediatric radiation-induced cataracts in retinoblastoma. Ophthalmology. 2005;112(9):1620-4. 
15. Portellos M, Buckley EG. Cataract surgery and intraocular lens implantation in patients with retinoblastoma. Arch Ophthalmol. 1998;116(4):449-52.

16. Sinha R, Titiyal JS, Sharma N, Vajpayee RB. Management of radiotherapy-induced cataracts in eyes with retinoblastoma. J Cataract Refract Surg. 2004;30(5):1145-6.

17. Osman IM, Abouzeid H, Balmer A, Gaillard MC, Othenin-Girard P, Pica A, et al. Modern cataract surgery for radiation-induced cataracts in retinoblastoma. $\mathrm{Br} J$ Ophthalmol. 2011:95(2):227-30.

18. Hollick EJ, Spalton DJ, Ursell PG, Pande MV, Barman SA, Boyce JF, et al. The effect of polymethylmethacrylate, silicone, and polyacrylic intraocular lenses on posterior capsular opacification 3 years after cataract surgery. Ophthalmology. 1999;106(1):49-55.

19. Sundelin K, Friberg-Riad Ylva, Östberg A, Sjöstrand J. Posterior capsule opacification with AcrySof ${ }^{\oplus}$ and poly(methylmethecrylate) intraocular lenses - comparative study with a 3-year follow-up. J Cataract Refract Surg. 2001;27(10):1586-90.

20. Verçosa IMC, Tartarella MB. Catarata na criança. Fortaleza, CE: Celigráfica, 2008. 319p 21. Hosal BM, Biglan AW. Risk factors for secondary membrane formation after removal of pediatric cataract. J Cataract Refract Surg. 2002;28(2):302-9.

22. Wilson ME, Elliot $L$, Johnson B, Peterseim MM, Rah S, Werner $L$, et al. AcrySof acrylic intraocular lenses implantation in children: clinical indications of biocompatibility. J AAPOS. 2001;5(6):377-80.

23. Hoehn ME, Irshad F, Kerr NC, Wilson MW. Outcomes after cataract extraction in young children with radiation-induced cataracts and retinoblastoma. J AAPOS. 2010; 14(3):232-4. 